\title{
Fusarium és Sarocladium okozta fertőzések szemészeti vonatkozásai és azok kezelése
}

\author{
Czakó Cecília dr. ${ }^{1}$. Sándor Gábor dr. ${ }^{1}$ - Popper-Sachetti Andrea dr. ${ }^{1}$ \\ Horváth Hajnalka dr. ${ }^{1}$ - Kovács Illés dr. ${ }^{1}$. Imre László dr. ${ }^{1}$ \\ Tóth Jeannette dr. ${ }^{2}$ - Birinyi Péter dr. ${ }^{3}$ - Nagy Zoltán Zsolt dr. ${ }^{1}$ \\ Simon Gyula dr. ${ }^{4}$. Szentmáry Nóra dr. ${ }^{1,5}$ \\ 'Semmelweis Egyetem, Általános Orvostudományi Kar, Szemészeti Klinika, Budapest \\ ${ }^{2}$ Semmelweis Egyetem Általános Orvostudományi Kar, Patológiai Intézet, Budapest \\ ${ }^{3}$ Mikszáth Gyógyszertár, Budapest \\ ${ }^{4}$ Mikromikomed Kft., Budapest \\ ${ }^{5}$ Klinik für Augenheilkunde, Universitätsklinikum des Saarlandes, Homburg/Saar, Németország
}

\begin{abstract}
A Fusarium-, Acremonium- és Sarocladium-gombafajok nevezéktana 2017-ben megváltozott. A morfológiailag homogén, de filogenetikailag heterogén fajokat, illetve fajkomplexeket ma már nukleinsav-összetételük szerint a MALDI-TOF MS-vizsgálat segítségével el lehet különíteni. Ez indokolta a taxonómiai besorolás módosítását. Közleményünkben a Fusarium-és Sarocladium-fajok okozta szaruhártya-gyulladás (keratitis) klinikai lefolyását ismertetjük, összefoglaljuk a diagnosztikus és kezelési lehetőségeket. Mindezek jelentős kihívást jelentenek a szemorvos számára. Súlyos szövődményekhez vezet a késői felismerés és kezelés, a folyamat gyors progressziója, a kórokozó átjutása a Descemet-membránon, a gombaellenes terápia korlátozott hozzáférhetősége és penetrációja, valamint a gyakori terápiarezisztencia. A diagnózis felállításához az anamnézisben szereplő trauma vagy kontaktlencse-viselés, PCR és MALDI-TOF MS-vizsgálat, konfokális mikroszkópia, a minta mikrobiológiai tenyésztése és a gyulladás területéból vett citológiai minta mikroszkópos vizsgálata vezet. A primeren választandó konzervatív terápia a lokálisan alkalmazott 5\%-os natamicin, illetve esetenként érzékenység meghatározását követően az 1\%-os vorikonazol vagy 0,15-0,25\%-os amfotericin B szemcsepp, ezenkívül a 0,02\%-os polihexametilén-biguanid (PHMB) szemcsepp használatának sikeréról is beszámoltak. Fusarium okozta keratitisben napi $2 \times 200 \mathrm{mg}$ vorikonazol tabletta adása is javasolt lehet. Terápiarezisztens esetekben korai, széles átmérőjü perforáló keratoplasztika (PKP) végzendő, épben történő trepanációval. Megkésett diagnózis és specifikus kezelés esetén a gombafonalaknak a Descemet-membránon történt átjutásával az esetek mintegy negyedében a látás elvesztése és a szemgolyó eltávolítása következik be. Jelen közleményünk öt, Fusarium-és Sarocladium-fajok okozta keratitis klinikai lefolyásának változatosságát is bemutatja. Orv Hetil. 2019; 160(1): 2-11.
\end{abstract}

Kulcsszavak: Fusarium, Sarocladium, Acremonium, keratitis, perforáló keratoplasztika

\section{Ocular manifestations and management of Fusarium and Sarocladium infections}

Since 2017, the nomenclature of Fusarium, Acremonium and Sarocladium species have changed, as these morphologically homogeneous, but phylogenetically heterogeneous species and species complexes may be differentiated using MALDI-TOF MS examination, analyzing nucleotic sequences. This resulted in taxonomical changes. We summarize the clinical course, diagnostic and therapeutic options of keratitis caused by Fusarium and Sarocladium. The challenge of Fusarium and Sarocladium keratitis management for an ophthalmologist lies in delayed diagnosis and therapy, fulminant progression and penetration of the Descemet's membrane, restricted availability, poor penetration of antifungal agents and therapy resistance. The diagnosis is based on the clinical history of corneal trauma or contact lens wear, PCR and MALDI-TOF MS, confocal microscopic examination, microbiological culture and light-microscopic analysis of corneal scrapings. As primary conservative treatment, $5 \%$ natamycin eye drops have to be used and with results of an antimycogram, topical $1 \%$ voriconazole or $0.15-0.25 \%$ amphotericin $\mathrm{B}$, in some cases $0.02 \%$ polyhexamethylene-biguanide (PHMB) may be applied. Fusarium keratitis may benefit from additional $2 \times 200 \mathrm{mg}$ oral voriconazole treatment, daily. In therapy resistant cases, early, large diameter penetrating keratoplasty (PKP) has to 
be performed, with complete removal of the infected area. With late diagnosis, delayed specific treatment and surgery, mycotic hyphae may penetrate the Descemet's membrane, leading to the loss of vision and enucleation in about every fourth patient. In our paper, we also present the heterogeneous clinical history of five Fusarium and Sarocladium keratitis cases.

Keywords: Fusarium, Sarocladium, Acremonium, keratitis, penetrating keratoplasty

Czakó C, Sándor G, Popper-Sachetti A, Horváth H, Kovács I, Imre L, Tóth J, Birinyi P, Nagy ZZs, Simon Gy, Szentmáry N. [Ocular manifestations and management of Fusarium and Sarocladium infections]. Orv Hetil. 2019; 160(1):2-11.

Beérkezett: 2018. július 24.; elfogadva: 2018. augusztus 15.)

\section{Rövidítések}

$\mathrm{BA}=($ blood agar $)$ véres agar; $\mathrm{CXL}=($ corneal crosslinking $)$ crosslinking kezelés; CzDA = Czapek-Dox-agar; DNS = dezoxiribonukleinsav; GMS $=($ Grocott-Gömöri methenamine silver) Grocott-Gömöri-festés; $\mathrm{KOH}=$ kálium-hidroxid MALDI-TOF MS = matrix-assisted laser desorption/ionization-time-of-flight mass spectrometry; MUTT = mycotic ulcer treatment trial; OCT $=$ (optical coherence tomography $)$ optikaikoherencia-tomográfia; PAS $=$ (periodic acid-Schiff $)$ perjódsav-Schiff; PCR $=$ (polymerase chain reaction) polimerázláncreakció; $\mathrm{PDA}=$ burgonya-dextróz agar; $\mathrm{PHMB}=$ polihexametilén-biguanid; $\mathrm{PKP}=$ (penetrating keratoplasty) perforáló keratoplasztika; SDA $=$ (Sabouraud dextrose agar) Sabouraud-dextróz agar; UVA = ultraibolya A

\section{Fusarium és Sarocladium}

\section{Fusarium}

A Fusarium név a latin „fusus” szóból származik, melynek jelentése orsó. A fonalas (köznapi néven: penész-) gombák közé tartozó Fusarium gombanemzetségbe hozzávetőlegesen ezer faj sorolható. Mivel filogenetikai szempontból heterogén, morfológiai szempontból többé-kevésbé homogén gombák csoportja, ma már „fajkomplexről” beszélünk. A talaj normálflórája részeként és növényi patogénként (leginkább gabonaféléken) található meg világszerte. Számos ártalmatlan species ismert, bizonyos csoportjaik azonban növényeket, állatokat és embereket egyaránt súlyosan megbetegíthetnek [1].

A Fusarium-speciesek burgonya-dextróz (PDA), Czapek-Dox (CzDA)-, véres (BA) és Sabouraud-dextróz (SDA) agaron jó növekedést mutatnak. Különféle fajok PDA-n fehér, levendulalila, lazacrózsaszín vagy szürkés kolóniákat képezhetnek, és a kolóniák változtathatják a színüket. Mikroszkópban vizsgálva a Fusarium szerkezete az Aspergillusra emlékeztet, a filamentumok 3-8 um átmérőjüek, átlátszóak (hyalin jellegúek, ez adja a hyalohyphomycosis elnevezést), és septumképződést mutatnak.

A Fusariumok pontos azonosítása a 'matrix-assisted laser desorption/ionization-time-of-flight mass spectrometry’ (MALDI-TOF MS) vizsgálat segítségével végezhető, mely a különféle fajkomplexeket nukleinsav-össze- tételük szerint különíti el. A MALDI szóösszetételt először 1985-ben használták, a TOF MS kifejezés a spektrométer típusára ('time-of-flight mass spectrometry') utal. A MALDI-TOF MS-vizsgálat ionizációs technikával dolgozik, mely első lépésben lézerenergia segítségével a mátrix eltávolítását végzi, elősegítve az így minimális fragmentálódással nagy molekulákból keletkező ionok azonosítását. Biomolekulák, mint például a dezoxiribonukleinsav elemzésére használják [2].

A Fusarium gombanemzetségbe tartozó gombák jellegzetesen macroconidiumot és microconidiumot is termelnek. A Fusariumot a Sarocladiumtól ívelt, több sejtet tartalmazó macroconidiuma segítségével különböztethetjük meg. A különféle Fusarium-speciesek pontos identifikálási módját Nelson és mtsai írták le [3].

\section{Fusariosis}

A Fusarium-speciesek okozta humán fertőzések viszonylag ritkák, a leggyakrabban a Fusarium solani (50\%) és a Fusarium oxysporum (20\%) okoz megbetegedést. Ezek lehetnek felszínes (keratitis, onychomycosis), lokálisan invazív és disszeminált fertőzések. Immunkompetens személyeknél a Fusarium-speciesek allergiás megbetegedést (sinusitis) okozhatnak, és Fusariummal fertőzött élelmiszer fogyasztását követően mycotoxicosis jelentkezhet. Gyengült immunrendszerű betegeknél nő a fusariosis kockázata, és gyorsan disszeminálttá válhat a fertőzés. A fertőzés a conidium belélegzésével szerezhető, de felszíni sérülésekhez (bőr) is kapcsolódhat, vagy fertőzött vizekből kerülhet az emberi szervezetbe. A disszeminált fertőzés az aspergillosist utánozhatja, hirtelen jelentkező láz, sinusitis, fájdalmas ecthyma gangrenosumhoz hasonló bőrlaesiók, tüdőérintettség és izomfájdalom formájában [4].

\section{Sarocladium}

A fonalas gombák közé tartozó Sarocladium gombanemzetségbe több mint száz species tartozik. Korábban a filogenetikailag összetett Acremonium-csoportba sorolták őket, 2017 óta azonban a MALDI-TOF MS-vizsgálatnak köszönhetően bebizonyosodott, hogy a Sarocladium 
külön csoportot képez [5]. Az ezt megelőző nevezéktanban Cephalosporumként voltak ismertek, mivel a $\beta$-laktámcsoportba tartozó cephalosporinokat termelik.

A Sarocladium-fajok kedvelik a vizet és a nedvességet, talajban és elpusztult növényi részeken találhatók meg világszerte, de jelen lehetnek a levegóben, légkondicionáló berendezésekben vagy építési törmelékeken is. Többségük betegséget általában nem okoz, néhány species azonban növényi, állati és emberi megbetegedést okozhat. Opportunista fertőzésként jelentkezhet eumycetoma, onychomycosis és hyalohyphomycosis formájában [6].

\section{Fusarium és Sarocladium okozta szembetegségek és azok epidemiológiája}

Fusarium és Sarocladium okozta blepharitis és conjunctivitis nem került leírásra az irodalomban, humán esetek tekintetében. Fusarium és Sarocladium okozta fertőzés következtében elsősorban keratitis figyelhető meg (1-5. ábra), amennyiben azonban a gombás fertőzés a szem hátsó szegmentumába terjed, endophthalmitis, illetve panophthalmitis alakulhat ki.

A gombás keratitisek előfordulása a mérsékelt égöv alatt 6-20\%, míg a trópusi éghajlaton az 50\%-ot is elér-
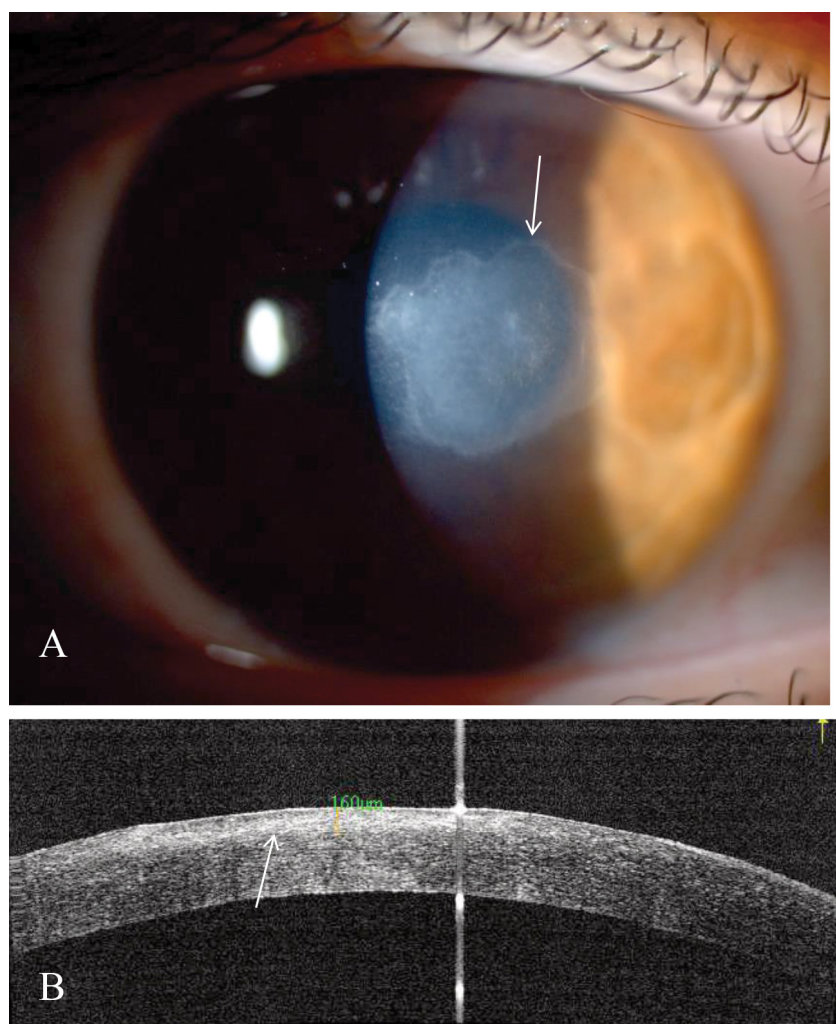

1. ábra

(A) Sarocladium strictum okozta, konzervatív terápiát követően gyógyult keratitis éles szélü, a centrumot elérő szaruhártyahege (nyíl). (B) Korábbi, gyulladásos szakban készült elülsőszegmens-OCT-vizsgálatnál a corneastroma felső részében található az infiltrátum, a mély stromát nem éri el (nyíl) (1. beteg)

OCT $=$ optikaikoherencia-tomográfia
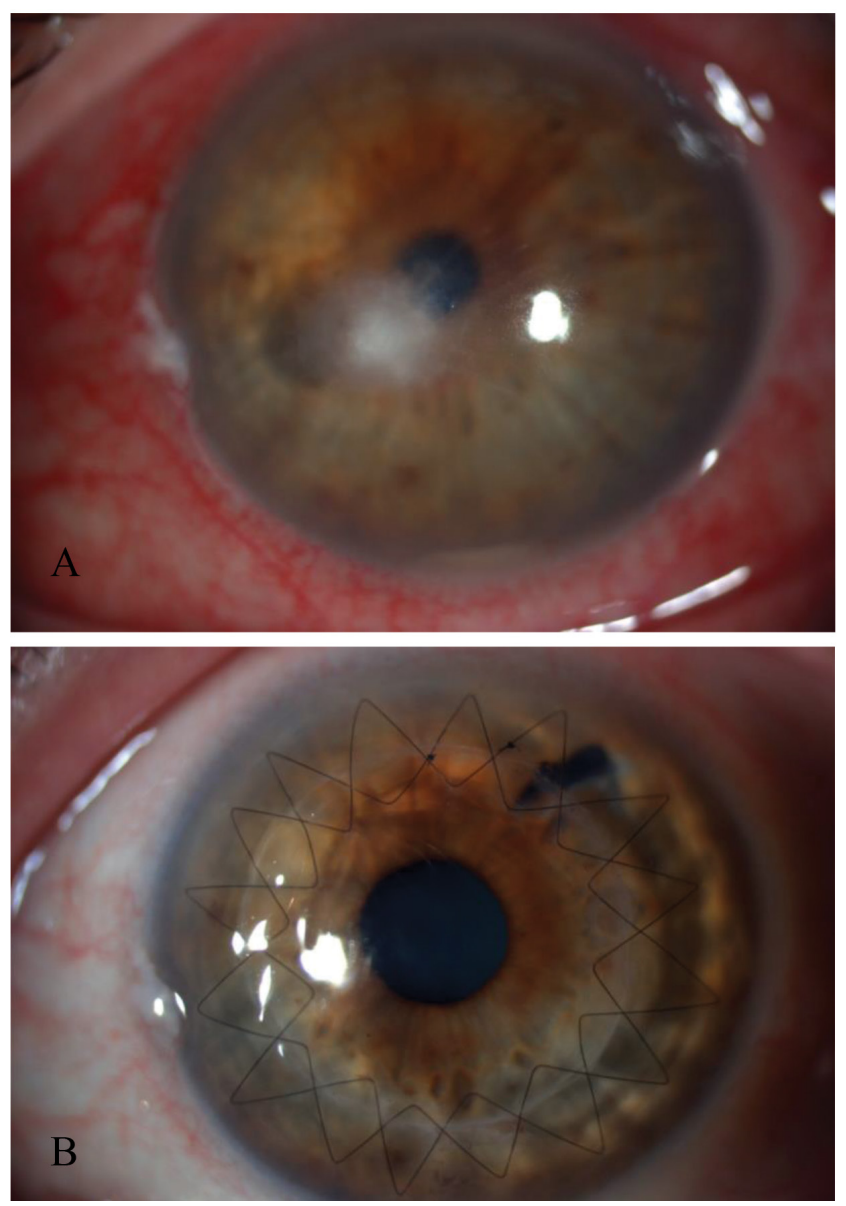

2. ábra

Fusarium okozta keratitis mély szaruhártya-infiltrátummal és az elülső csarnok alján hypopyonnal (A), majd sürgősséggel végzett ('à chaud') centrális perforáló szaruhártya-átültetést követôen, varratszedés elött (B) (2. beteg)

heti a fertőző szaruhártya-gyulladások körében [7]. A háttérben álló leggyakoribb kórokozók a fonalas gombák közül a Fusarium, az Aspergillus és a Sarocladium, míg a sarjadzó gombák közül a Candida-fajok. Európában a leggyakoribb a Candida- (32\%), majd ezt követően az Aspergillus- és a Fusarium- (14\%) keratitisek előfordulása [8].

A Fusarium okozta keratitisek incidenciája kontinensenként eltérő. Kínában a gombás keratitises esetek 65\%át, az egyesült államokbeli Floridában 63\%-át, Dél-Indiában 47\%-át, Franciaországban 21\%-át teszik ki [9-11]. Hazánkban Fusarium-keratitis témakörben csak esetleírások születtek [12,13], incidenciáról nincsen adatunk. A Sarocladium okozta keratitis előfordulásával kapcsolatosan adatokat a nemzetközi irodalom nem közöl.

2006-ban a Fusarium-keratitisek gyakorisága robbanásszerúen megnőtt a Bausch and Lomb cég által gyártott ReNu With MoistureLoc tárolófolyadékot használók körében. Az Egyesült Államokban közel 200, Szingapúrban 66, Kínában, Indiában és Európában pedig néhány esetet regisztráltak [14]. A járvány kialakulásához hozzájárulhatott a készítmény nem kontrollált tárolási és szállítási hőmérséklete, valamint a Fusarium biofilmképző tulajdonsága [15]. 

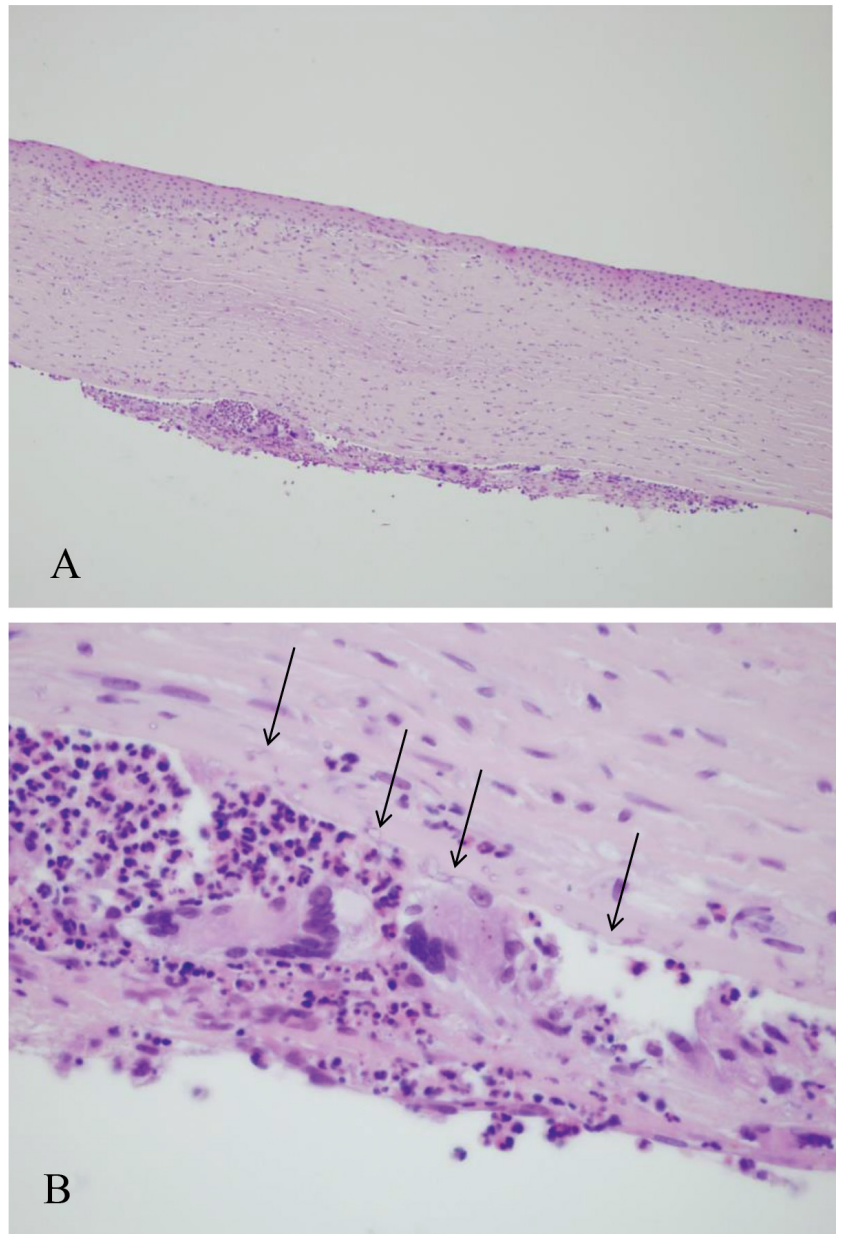

3. ábra

Perforáló szaruhártya-átiiltetést követően az explantált szaruhártyakorongban hematoxilin-eozin (HE) festéssel a Descemet membrán környezetében granulomatosus gyulladás látható (eredeti nagyítás $10 \times)(\mathrm{A})$, a gombafonalak a Descemet-membránt áttörik (nyilak), és óriássejtek vannak jelen (eredeti nagyítás $60 \times)(B)(2$. beteg)

A mikroorganizmusok az intakt corneaepitheliumon nem jutnak át, a betegség kialakulásának leggyakoribb prediszponáló faktora a gyulladást megelőző okuláris trauma (föleg növényi eredetû vagy földdel szennyezett idegen test által), de további rizikófaktorok a kontaktlencse-viselés (a szaruhártyahám sérülése és kontaktusa fertőzött vízzel), a megelôzző szemészeti mútét, a szemfelszíni betegség, valamint a kortikoszteroidterápia (szisztémás és lokális) [16].

\section{A Fusarium és Sarocladium okozta keratitis tünetei és klinikai képe}

A Fusarium- és Sarocladium-keratitis jellemzője a gyors kialakulás, a hirtelen jelentkező fájdalom, a könnyezés, a fényérzékenység (fotofóbia) és a látáscsökkenés. Réslámpás vizsgálattal tömött, fehéres, életlen szélű szaruhártyahomály figyelhető meg (beszưrődés, infiltrátum) (2/A, 4/A és $6 / A$ ábra), melynek széleiből apró fehéres finom rövid nyúlványok indulnak ki $(4 / A$ és $6 / A$ ábra).
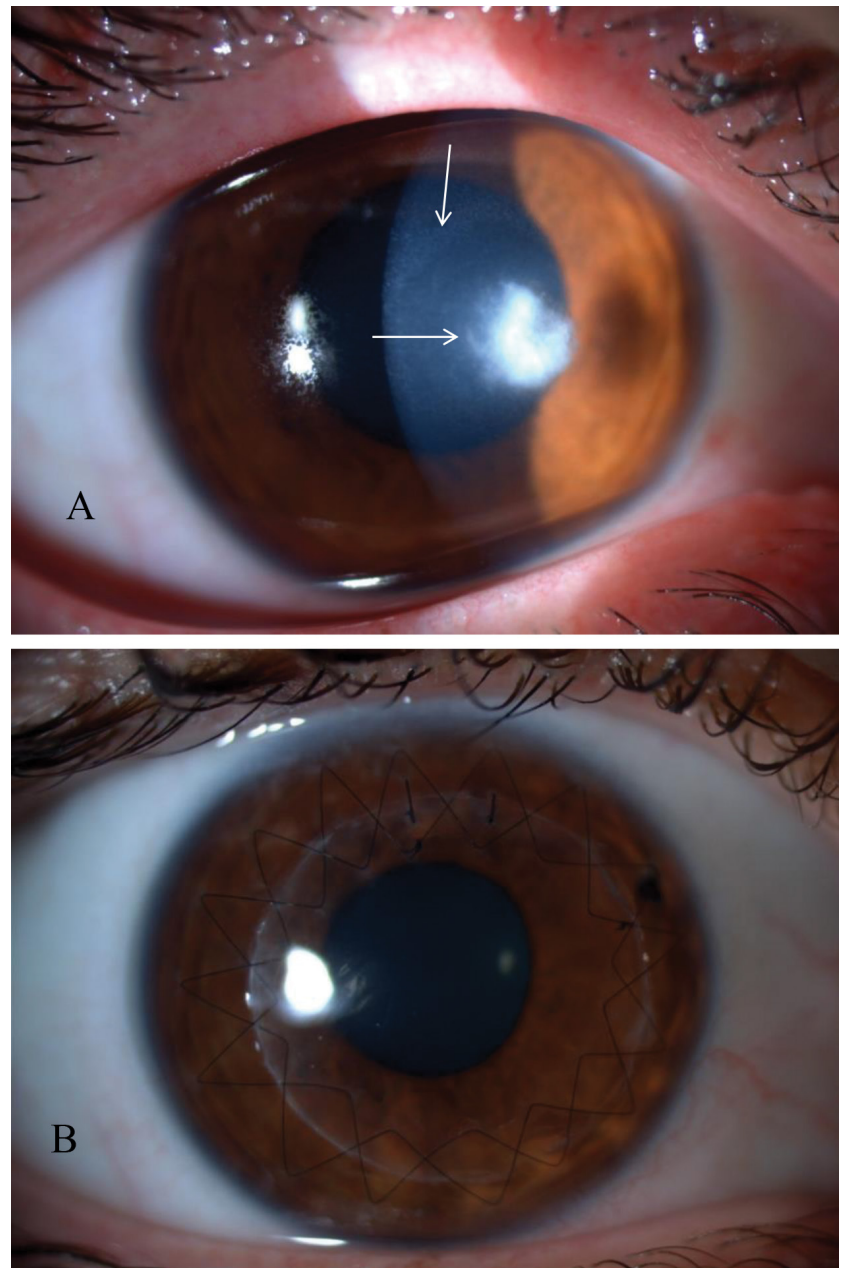

4. ábra

Sarocladium kiliense okozta keratitis Wessely-gyúrúvel (függőle ges nyíl) (A), majd 'à chaud' excentrikus perforáló szaruhártyaátültetést követően, varratszedés előtt (B) (3. beteg). Az infiltrá tum szélén a finom nyúlványok jól láthatók (vízszintes nyíl) (A)

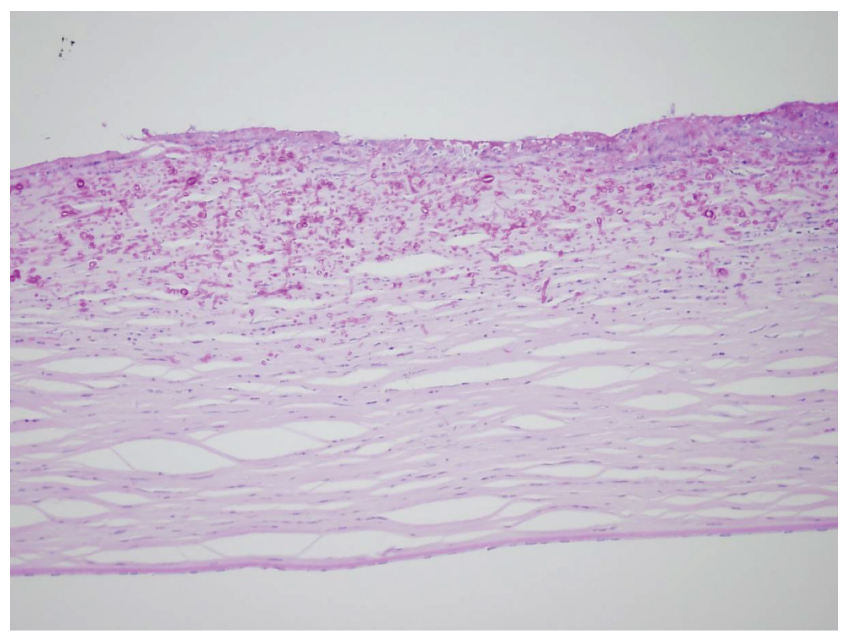

5. ábra

Perforáló szaruhártya-átültetést követően az explantált szaruhártyakorongban PAS-festéssel a középső stromáig terjedő gombafonalak és gyulladásos sejtek láthatók - eredeti nagyítás $20 \times(3$. beteg)

PAS $=$ perjódsav-Schiff-reagens 
1. táblázat |A Fusarium és Sarocladium okozta keratitisek diagnosztikai módszerei, szenzitivitásuk szerinti sorrendjükben

\begin{tabular}{|c|c|c|c|}
\hline $\begin{array}{l}\text { Vizsgálati módszer } \\
\text { (szenzitivitás, specificitás) }\end{array}$ & Mit vizsgálunk? & Előny & Hátrány \\
\hline $\begin{array}{l}\text { PCR-vizsgálat } \\
(\text { Sz: } 90-100 \%, \text { Sp: 97-100\%) [18] }\end{array}$ & Gomba-DNS kimutatása & Gyors, magas szenzitivitás & Invazív \\
\hline $\begin{array}{l}\text { MALDI-TOF MS } \\
(\text { Sz: } 98,6 \%, \text { Sp: 100\%) [19] }\end{array}$ & Gombanukleinsav kimutatása & Gyors, magas szenzitivitás & $\begin{array}{l}\text { Invazív } \\
\text { Szúk adatbázis }\end{array}$ \\
\hline $\begin{array}{l}\text { Konfokális mikroszkópia } \\
(\text { Sz: 89-94\%, Sp: 78-97\%) [20] }\end{array}$ & Gombafonalak in vivo kimutatása & $\begin{array}{l}\text { Gyors, noninvazív, magas } \\
\text { szenzitivitás } \\
\text { Terápiás követésre alkalmas }\end{array}$ & $\begin{array}{l}\text { Tapasztalt vizsgálót igényel } \\
\text { Kooperáció szükséges } \\
\text { Denz infiltrátum/heg takarhat }\end{array}$ \\
\hline $\begin{array}{l}\text { Mikrobiológiai tenyésztés } \\
(\text { Sz: } 40-59 \%, \text { Sp: } 33-78 \%) \\
{[18,21]}\end{array}$ & $\begin{array}{l}\text { Gombatelepek in vitro vizsgálata } \\
\text { PDA, CzDA, BA, SDA agar }\end{array}$ & $\begin{array}{l}\text { Könnyen elérhető, } \\
\text { egyszerű kivitelezés } \\
\text { A gomba érzékenysége antimikoti- } \\
\text { kumokra meghatározható }\end{array}$ & $\begin{array}{l}\text { Invazív } \\
\text { Tapasztalt vizsgálót igényel } \\
\text { Lassú eredmény }\end{array}$ \\
\hline $\begin{array}{l}\text { Citológiai és szövettani vizsgálat } \\
(\text { Sz: } 20-70 \%, \text { Sp: } 18-35 \%) \text { [18] }\end{array}$ & $\begin{array}{l}\text { Gombafonalak in vitro kimutatása } \\
\text { Gram-, Giemsa-, PAS-, GMS-, } \\
\text { KOH-festés }\end{array}$ & Könnyen elérhető, relatíve gyors & $\begin{array}{l}\text { Invazív } \\
\text { Tapasztalt vizsgálót igényel }\end{array}$ \\
\hline $\begin{array}{l}\text { Elülsőszegmentum-OCT } \\
(\mathrm{N} / \mathrm{A})\end{array}$ & $\begin{array}{l}\text { Infiltrátum mélységének } \\
\text { megítélése }\end{array}$ & $\begin{array}{l}\text { Gyors, noninvazív, nonkontakt } \\
\text { Terápiás követésre alkalmas }\end{array}$ & $\begin{array}{l}\text { Nemspecifikus, kiegészítő } \\
\text { vizsgálat }\end{array}$ \\
\hline
\end{tabular}

$\mathrm{BA}=$ véres agar; CzDA = Czapek-Dox-agar; DNS = dezoxiribonukleinsav; GMS = Grocott-Gömöri-festés; KOH = kálium-hidroxid; N $/ \mathrm{A}=$ nem elérhető; OCT = optikaikoherencia-tomográfia; PAS = perjódsav-Schiff; PCR = polimeráz-láncreakció; PDA = burgonya-dextróz agar; SDA = Saboraud-dextróz agar

Az infiltrátum felett a szaruhártya jellemzően hámfosztott. Esetenként az infiltrált terület körül Wessely-immungyưrü jelenhet meg $(4 / A$ ábra $)$. Emellett a gomba mélyebb rétegekbe történő bejutását követően adaptált immunmediált gyulladásos reakció indul be, melynek következménye a környezetben kialakuló kisebb-nagyobb fokú szövetnecrosis. Amennyiben a specifikus kezelés késik, a gombafonalak elérik, majd áttörik a Descemet-membránt $(2 / A$ és $6 / A$ ábra), és a csarnokban gyulladásos izzadmány (hypopyon) jelenik meg. Ha a gombafonalak a csarnokba jutnak, a gyulladás továbbterjedhet a szem hátsó szegmentumára is, és gombás endophthalmitis alakulhat ki, mely nem uralható esetekben a szemgolyó elvesztésével jár [17].

\section{Diagnosztika}

A Fusarium-és Sarocladium-fajok okozta keratitisek diagnosztikájában használatos módszereket az 1 . táblázat mutatja be [18-21]. Más keratitisekhez hasonlóan csak a megfelelő diagnózis időben történő felállításával lehet a specifikus terápia késlekedését és annak súlyos következményeit elkerülni [22]. Éppen ezért a szaruhártya-gyulladással küzdő beteg a háziorvosi ellátásból rögtön szemész szakorvoshoz kell, hogy kerüljön, illetve terápiarezisztencia esetén (2-3 nap!) a szemorvos hármas ellátási szintű intézménybe köteles irányítani a beteget.

A helyes diagnózis felállításához elengedhetetlen a megfelelő anamnézis felvétele, hiszen a növényi anyaggal történt szennyeződés és a kontaktlencse-viselés hazánkban a legfontosabb kockázati tényezők. E mellett a klinikai kép is segíthet a diagnózis felállításában, hiszen a Fu- sarium és Sarocladium okozta infiltrátumok széle jellemzően nyúlványos (4/A és $6 / A$ ábra).

A konfokális mikroszkópia gyors és noninvazív képalkotó módszer, mely lehetôvé teszi a cornea különböző rétegeiben elhelyezkedő gombafonalak in vivo kimutatását, és segíti a diagnózis megerősítését [23]. A módszer hátránya, hogy tapasztalt vizsgáló szükséges a helyes diagnózis felállításához [24].

Az infiltrátumból vett szaruhártya-kaparék polimerázláncreakciót (PCR) és MALDI-TOF MS-módszert használva vizsgálható. Ilyenkor 4-8 óra alatt, magas szenzitivitással és specificitással határozható meg a gomba jelenléte és nemzetsége, a módszer azonban a hazai szemészeti gyakorlatban nem terjedt el [25], mivel a Nemzeti Egészségbiztosítási Alapkezelő ennek költségeit nem fedezi. Az Intézetünkbe kerülő betegeknél MALDI-TOF MS-vizsgálat indokolt esetekben (szaruhártyabetegségekkel foglalkozó szemész szakorvos javaslata szerint) végezhető.

A gombafonalak jelenlétét az infiltrátumból vett kaparék Gram-, Giemsa-, perjódsav-Schiff (PAS)-, GrocottGömöri (GMS)-festésével és kálium-hidroxid (KOH)preparátum segítségével, direkt mikroszkópos vizsgálattal is megerősíthetjük.

Az in vivo, noninvazív konfokális mikroszkópia és az in vitro invazív direkt mikroszkópos, a PCR-, valamint a MALDI-TOF MS-vizsgálatok is alkalmasak a gombafonalak igazolására, jelentős hátrányuk azonban, hogy az adott species antimikotikumokkal szembeni érzékenysége ezen módszerekkel nem vizsgálható. A PCR-, a MALDI-TOF MS- és a direkt mikroszkópos vizsgálatok esetén azonban a gombanemzetség azonosítható, így 
ezek a vizsgálatok segítenek a primeren választandó kezelés meghatározásában [26].

Éppen ezért elengedhetetlen a mikrobiológiai leoltás és az azt követő mikrobiológiai tenyésztés, noha ennek a vizsgálati technikának a szenzitivitása a fenti módszereknél alacsonyabb. Esetenként a fertőzött terület leoltópálcával történő érintése is pozitív eredményhez vezet, azonban kis mennyiségú fertőzött szövet eltávolítása, mikrobiológiai leoltása és tenyésztése jelentősen növeli a mikrobiológiai munka sikerét, különösen amennyiben lassan növekvő gomba tenyésztését végzik [27]. A mikrobiológiai tenyésztés PDA, CzDA, BA és SDA agaron történik, és legalább 48-72 órát vesz igénybe, de sokszor néhány hétre is szükség van pozitív eredményhez. Gombás fertőzöttség tekintetében negatív eredmény a legkorábban két hét után adható ki.

Amennyiben az itt felsorolt módszerek segítségével nem kapunk helyes diagnózist, a fertőzött terület egy 10-20 um vastag területének sebészi kimetszésével (keratectomia) és az ezt követő szövettani vizsgálat segítségével kaphatunk diagnózist. Ezt a módszert azonban csak a diagnózis hiánya és terápiarezisztencia esetén alkalmazzuk [28].

A fenti módszerek mellett az elmúlt években az elülsószegmentum-OCT-vizsgálat bevezetése és elterjedése könnyítette meg a szaruhártyával foglalkozó szakemberek munkáját. Ezzel a módszerrel objektív módon határozhatjuk meg a fertőzött terület kiterjedését és időbeli változását [29].

\section{Terápia}

A Fusarium és Sarocladium okozta szaruhártya-gyulladásban javasolt konzervatív és sebészi kezelési módot a 2. táblázat tartalmazza.

A fertőzéses szaruhártya-gyulladások közül a legnagyobb kihívással a gombás keratitisek terápiája jár, a diagnózis jellemzően késői felállítása, a gombaellenes szerek korlátozott hozzáférhetősége, rossz penetrációs képessége, valamint a kórokozók gyakori terápiarezisztenciája miatt. Emellett a Fusarium és Sarocladium okozta keratitisek konzervatív kezelése még kifejezettebb kihívást jelent, a gyakran multirezisztens törzsek miatt.

Amennyiben Fusarium vagy Sarocladium jelenléte igazolódik a szaruhártyában, a primeren választandó konzervativ kezelés (az érzékenység ismeretének hiányában) az 5\%-os natamicin szemcsepp, melynek elérhetősége a magas költsége miatt hazánkban korlátozott. Fontos kiemelnünk azonban, hogy jelenleg hazánkban mind a bentfekvő, mind az ambuláns ellátásban elérhető az 5\%-os natamicin szemcsepp, és a Nemzeti Egészségbiztosítási Alapkezelő felé benyújtott kérvény pozitív elbírálása esetén költsége térítésre kerül.

A natamicin első bevezetésére 1960-ban került sor, azóta más antimikotikus szemcsepp nem került forgalomba a világon. Az érzékenységi spektrum ismeretében a kon- zervatív kezelés a későbbiekben módosítható, óránként adható $1 \%$-os vorikonazol vagy $0,15-0,25 \%$-os amfotericin B szemcsepp [30].

Gombaellenes szemcseppek alkalmazása esetén elengedhetetlen a szaruhártyahám (rendszeres) eltávolítása, hiszen csak így biztosítható a viszonylagosan nagy molekulasúlyú hatóanyag bejutása a szaruhártyastromába [31].

A 2,5 $\mu \mathrm{g} / 0,1 \mathrm{ml}$ amfotericin B és az $50 \mu \mathrm{g} / 0,1 \mathrm{ml}$ vorikonazol intrastromalisan is alkalmazható, segítségükkel a szaruhártyastromában nagyobb gyógyszer-koncentráció és így a gyógyulási idő lerövidülése érhető el [32, 33]. Szintén kedvező eredményeket írtak le hypopyonnal járó fertőzésekben csarnoköblítés és intracameralis 5 $\mu \mathrm{g} / 0,1 \mathrm{ml}$ amfotericin B vagy $10-50 \mu \mathrm{g} / 0,1 \mathrm{ml}$ vorikonazol alkalmazása esetén $[34,35]$. Natamicin a nagy molekulamérete miatt intracameralisan nem adható.

Az utóbbi években több közlemény számolt be a 0,02\%-Os PHMB jótékony hatásáról antifungalis terápiarezisztens Fusarium-keratitisben. A PHMB alkalmazása sok intézetben eredményesen bevezetésre került az antimikotikus szerek mellett a klinikai gyakorlatban [36]. Emellett in vitro tanulmány számolt be az 1\%-os ezüstnitrát gombaölő hatásáról, amfotericin B-, flukonazol- és ketokonazolrezisztens Fusarium-species esetén [37].

Fusarium és Sarocladium okozta keratitisben kortikoszteroidtartalmú szemcsepp adása kontraindikált. Súlyos gyulladásos formákban gyulladáscsökkentő hatásának eredményességéről, a lokális antimikotikus kezelés kiegészítéseként, nem számolnak be tanulmányok az irodalomban.

Sarocladium okozta keratitisben nem egyértelmú az álláspont, hogy szükséges-e orális vagy intravénás antimikotikumok alkalmazása. A 'MUTT 2' tanulmányban a lokálisan alkalmazott antifungalis szemcseppek mellett a betegek napi $2 \times 200 \mathrm{mg}$ vorikonazoltablettában részesültek. A 'MUTT 2' tanulmány Fusarium okozta keratitisek esetén kevesebb perforációval járó esetet és az infiltrátum méretének jelentősebb csökkenését írta le, szisztémás terápiában is részesülő betegek esetén. Emiatt Fusarium okozta keratitisben, noha a gombafonalak a Descemet-membránt még nem penetrálták, szisztémás vorikonazolkezelés adását a 'MUTT 2' javallja. Ugyanakkor, a szisztémás gombaellenes kezelés mellett megjelent mellékhatások miatt vorikonazoltabletta használata nem egyértelmúen ajánlott a tanulmány szerint. Intravénás vorikonazolterápia, rendkívül magas költsége miatt, nem került használatba a gyakorlatban [38].

Fusarium és Sarocladium okozta keratitisben jellemzően nem a szaruhártya perforációja jelenti a mútéti indikációt. Amennyiben a konzervatív terápia mellett a fertőzött terület mérete növekszik, vagy ha multirezisztens kórokozóval állunk szemben, sürgôsséggel PKP végzendő. Ilyenkor mindenképpen az épben kell, hogy történjen a kimetszés (nagyméretű PKP), ellenkező esetben a betegség visszatér. Emellett nagyon fontos, hogy a PKP-ra ilyen esetekben a gombafonalak Descemet- 
2. táblázat | Fusarium és Sarocladium okozta keratitisek konzervatív és sebészi kezelési módjai

\begin{tabular}{|c|c|c|}
\hline \multicolumn{3}{|l|}{ Konzervatív terápia } \\
\hline \multirow[t]{5}{*}{ Szemcsepp } & Natamicin 5\% & $\begin{array}{l}\text { Fusarium és Sarocladium esetén az első választandó szer! } \\
\text { - Rossz penetráció } \\
\text { - Drága, nehezen elérhető }\end{array}$ \\
\hline & Vorikonazol 1\% & $\begin{array}{l}\text { Fusarium és Candida ellen is hatásos szer } \\
\text { + Jó penetráció }\end{array}$ \\
\hline & Amfotericin B $0,15-0,25 \%$ & $\begin{array}{l}\text { + Olcsó, könnyen beszerezhető } \\
\text { - Rossz penetráció } \\
\text { - Epitheltoxicitás }\end{array}$ \\
\hline & PHMB 0,002\% & $\begin{array}{l}\text { Antifungalis szerekre nem reagáló esetekben } \\
\text { - Rossz penetráció }\end{array}$ \\
\hline & Ezüst-nitrát 1\% & $\begin{array}{l}\text { Antifungalis szerekre nem reagáló esetekben } \\
\text { - Csak in vitro tanulmány }\end{array}$ \\
\hline Tabletta & $\begin{array}{l}\text { Vorikonazol } 2 \times 200 \mathrm{mg} / \text { die } \\
(2 \times 200 \mathrm{mg})\end{array}$ & $\begin{array}{l}\text { Fusarium-keratitis esetén adható, a fertôzés cornealis penetrációja nélkül is! } \\
\text { Egyéb fonalas gombáknál penetráció, endophthalmitis esetén javasolt }\end{array}$ \\
\hline \multirow[t]{2}{*}{ Intrastromalis injekció } & Vorikonazol $50 \mu \mathrm{g} / 0,1 \mathrm{ml}$ & $\begin{array}{l}\text { Szemcseppre nem reagáló esetekben } \\
\text { Nagyobb koncentráció a fertőzés helyén }\end{array}$ \\
\hline & Amfotericin B 2,5 $\mu \mathrm{g} / 0,1 \mathrm{ml}$ & $\begin{array}{l}\text { Szemcseppre nem reagáló esetekben } \\
\text { Nagyobb koncentráció a fertőzés helyén }\end{array}$ \\
\hline \multirow[t]{2}{*}{ Intracameralis injekció } & Vorikonazol $10-50 \mu \mathrm{g} / 0,1 \mathrm{ml}$ & Hypopyonnal járó esetekben \\
\hline & Amfotericin B $5 \mu \mathrm{g} / 0,1 \mathrm{ml}$ & Hypopyonnal járó esetekben \\
\hline \multirow[t]{2}{*}{ Intravitrealis injekció } & Vorikonazol $10-50 \mu \mathrm{g} / 0,1 \mathrm{ml}$ & Endophthalmitis esetén \\
\hline & Amfotericin B $5-10 \mu \mathrm{g} / 0,1 \mathrm{ml}$ & Endophthalmitis esetén \\
\hline \multicolumn{3}{|l|}{ Mútéti terápia } \\
\hline Perforáló keratoplasztika & PKP & $\begin{array}{l}\text { Súlyos, konzervatív terápiára nem reagáló, gyorsan progrediáló gyulladás esetén } \\
\text { Épben történő kimetszés! }\end{array}$ \\
\hline \multirow[t]{2}{*}{$\begin{array}{l}\text { Fotodinámiás terápia } \\
\text { (PDT) }\end{array}$} & $\begin{array}{l}\text { Crosslinking } \\
\text { (Riboflavin szemcsepp + UVA } \\
\text { sugárzás) }\end{array}$ & $\begin{array}{l}\text { Súlyos, konzervatív terápiára nem reagáló, a cornea beolvadásával járó } \\
\text { gyulladás esetén, amennyiben PKP nem jön szóba } \\
\text { + Antimikrobiális hatás (oxigén-szabadgyökök) } \\
\text { + A cornea rigiditásának következtében a gombák penetrációja akadályozott } \\
\text { lehet }\end{array}$ \\
\hline & $\begin{array}{l}\text { Bengálvörös PDT } \\
\text { (Bengálvörös cseppek + } 518 \mathrm{~nm} \\
\text { sugárzás) }\end{array}$ & $\begin{array}{l}\text { Súlyos, konzervatív terápiára és CXL-re nem reagáló, a cornea beolvadásával } \\
\text { járó gyulladás esetén, amennyiben PKP nem jön szóba } \\
\text { + Antimikrobiális hatás (oxigén-szabadgyökök) }\end{array}$ \\
\hline
\end{tabular}

$\mathrm{CXL}=$ crosslinking kezelés $\mathrm{PDT}=$ fotodinámiás terápia $\mathrm{PKP}=$ perforáló keratoplasztika; $\mathrm{UVA}=$ ultraibolya $\mathrm{A} ;+$ = előny; $-=$ hátrány

3. táblázat | Fusarium-és Sarocladium-keratitises eseteink

\begin{tabular}{|c|c|c|c|c|c|c|c|}
\hline & Életkor, nem & Anamnézis & Kezdeti V & Gomba & $\begin{array}{l}\text { Terápia } \\
\text { (konzervatív) }\end{array}$ & $\begin{array}{l}\text { Terápia } \\
\text { (mútét) }\end{array}$ & Jelen V \\
\hline $\begin{array}{l}\text { 1. beteg } \\
\text { (1. ábra) }\end{array}$ & 28 éves nő & $\mathrm{KL}$ & 0,5 & $\begin{array}{l}\text { Sarocladium strictum } \\
\text { (É: natamicin) }\end{array}$ & $\begin{array}{l}5 \% \text { Natamicin }+ \\
0,02 \% \text { PHMB szemcsepp }\end{array}$ & - & 1,0 \\
\hline $\begin{array}{l}\text { 2. beteg } \\
\text { (2. és 3.ábra) }\end{array}$ & 67 éves nő & $\begin{array}{l}\text { Trauma } \\
\text { (dióhéj) }\end{array}$ & 0,3 & $\begin{array}{l}\text { Fusarium sp. } \\
\text { (É: vorikonazol) }\end{array}$ & $\begin{array}{l}1 \% \text { Vorikonazol + } \\
0,02 \% \text { PHMB szemcsepp }\end{array}$ & PKP & 0,3 \\
\hline $\begin{array}{l}\text { 3. beteg } \\
\text { (4.és 5. ábra) }\end{array}$ & 27 éves nő & $\mathrm{KL}$ & 0,4 & $\begin{array}{l}\text { Sarocladium kiliense } \\
\text { (É: natamicin, M: vorikonazol) }\end{array}$ & $\begin{array}{l}\% \text { Vorikonazol + } \\
1 \% \text { Ezüst-nitrát szemcsepp }\end{array}$ & PKP & 1,0 \\
\hline 4. beteg & 44 éves nő & $\mathrm{KL}$ & 0,5 & $\begin{array}{l}\text { Fusarium oxysporum complex } \\
\text { (É: natamicin, vorikonazol) }\end{array}$ & $\begin{array}{l}5 \% \text { Natamicin }+ \\
0,02 \% \text { PHMB szemcsepp }\end{array}$ & PKP & 0,7 \\
\hline $\begin{array}{l}\text { 5. beteg } \\
\text { (6. ábra) }\end{array}$ & 63 éves férfi & $\mathrm{KL}$ & $\mathrm{kml}$ & $\begin{array}{l}\text { Fusarium oxysporum complex } \\
\text { (R: multirezisztens) }\end{array}$ & $\begin{array}{l}0,25 \% \text { Amfotericin } \mathrm{B}, \text { majd } 5 \% \\
\text { natamicin szemcsepp }+2 \times 100 \\
\text { mg Itraconazol tabletta }\end{array}$ & $\begin{array}{l}3 \times \mathrm{PKP} \\
\text { Enucleatio }\end{array}$ & - \\
\hline
\end{tabular}

É = érzékeny; $\mathrm{KL}$ = kontaktlencse; $\mathrm{kml}$ = kézmozgáslátás; $\mathrm{M}$ = mérsékelten érzékeny; $\mathrm{PHMB}$ = polihexametilén-biguanid; PKP = perforáló keratoplasztika; $\mathrm{R}$ = rezisztens; $\mathrm{sp}=$ species; $\mathrm{V}$ = legjobb korrigált látóélesség 
membránon történő penetrációja - és így a fertőzés elülső csarnokba jutása - előtt kerüljön sor [39]. A gombás fertőzés mélységének objektív megítélésére elülsőszegmentum-OCT-t használunk [29]. Amennyiben a Fusari$u m$ mégis az elülső csarnokba jut, irodalmi adatok szerint a betegek mintegy 24\%-ában kerül sor a későbbiekben enucleatióra [40]. A mütét végén ilyenkor is javasolt minden esetben az elülső csarnokba amfotericin B-t vagy vorikonazolt juttatni.

Elülső lamelláris keratoplasztika Fusarium és Sarocladium okozta keratitisben kontraindikált, a fertőzés gyakori recidívája miatt [41].

Terápiarezisztens fertőzéses keratitisben fotodinámiás terápia bevezetésére is több esetben sor került. Ennek egyik módja a crosslinking (CXL) kezelés [42]. Ilyenkor az oxigén-szabadgyökök antimikrobiális hatásának kihasználása történik. Emellett a fotoszenzibilizáló szerként használt riboflavin és az UVA besugárzás hatására a szaruhártya-gyulladás következtében zajló litikus folyamatok is lassíthatók/megállíthatók [43] (2. táblázat).

Fusarium okozta keratitis sikeres kezeléséról CXL segítségével néhány esetben már beszámoltak, Sarocladium okozta keratitis eredményes kezeléséról azonban ez idáig még nem született leírás az irodalomban $[44,45]$. Fusarium okozta keratitisben bengálvörös és $518 \mathrm{~nm}$ hullámhosszú fény alkalmazása is sikert ért el [46].

\section{Eseteink}

2015 és 2018 júniusa között 5, Fusarium vagy Sarocladium okozta keratitist diagnosztizáltunk Klinikánkon. A betegek adatait a 3. táblázat szemlélteti.

Az egyes esetekben az első panaszok megjelenése és a helyes diagnózis felállítása között eltelt idő sorban 4 hét, 5 hét, 3 és fél hét, 3 és fél hét, illetve 5 hét volt. Egy esetben az anamnézisben a szem sérülése szerepelt, négy beteg viselt lágy kontaktlencsét (a kontaktlencsék pontos típusát illetóen nem állnak rendelkezésünkre adatok). A fonalas gombák három esetben natamicinérzékenynek, három esetben vorikonazolérzékenynek, egy esetben multirezisztensnek bizonyultak.

Egy esetben a gyulladás 5\%-os natamicin szemcsepp segítségével gyógyult (5 hónapos kezelés), a beteg látóélessége teljes maradt (1. eset; 1 ábra).

Három esetben (2-4. eset; 2-5. ábra) láttunk progressziót az érzékenységnek megfelelő lokális kezelés mellett (3-4 nap eltelte után), amely miatt PKP mellett döntöttünk (5-7 nappal az érzékenységnek megfelelő kezelés megkezdése után). Ezekben az esetekben a követési idő alatt keratitisrecidívát nem észleltünk. A lokális antimikotikus kezelést a 2. esetben a PKP után 5 hónapon át folytattuk. Az 1. és a 4 . esetben a szövettan igazolta a fertőzött terület épben történt kimetszését, ezért lokális gombaellenes kezelést a hisztológiai eredményt követően nem alkalmaztunk. A PKP-val operált betegek közül jelenleg a 2. eset látóélessége nem teljes, corticonuclearis
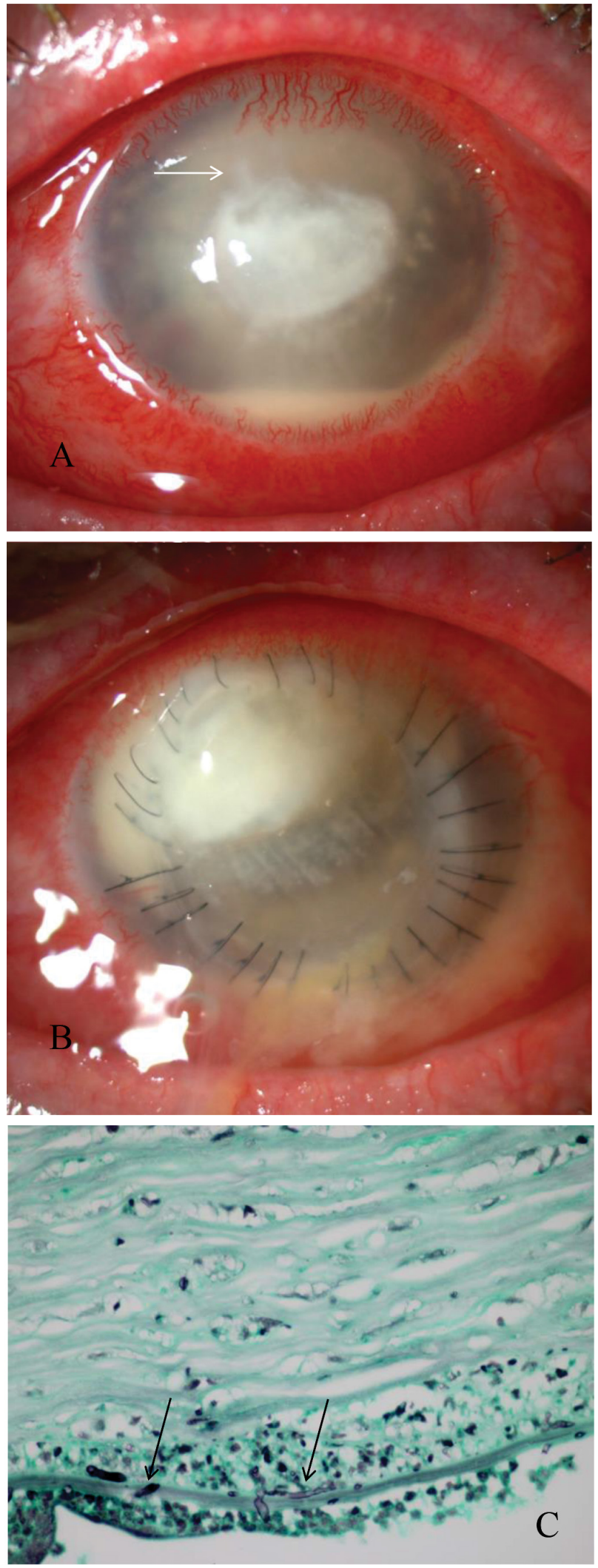

6. ábra

Multirezisztens Fusarium oxysporum okozta súlyos keratitis képe centrális szaruhártya-infiltrátummal és hypopyonnal (A), majd a perforáló szaruhártya-átültetést három és fél héttel követően a donorkorongban ismét visszatérő infiltrátummal (B) (5. beteg). Az infiltrátum szélén a finom nyúlványok jól láthatók (vízszintes nyíl) (A). Grocott-Gömöri (GMS)-festés (C) igazolta a Descemet-membránon átérő gombafonalakat (függóleges nyilak) (eredeti nagyítás $60 \times$ ) 
cataracta miatt mútétje már tervezett. Szövettani vizsgálat segítségével a 2. és az 5. esetben a gombafonalak Descemet-membránon történt penetrációja volt igazolható (3. és 6. ábra), a többi esetben Fusarium vagy Sarocladium a Descemet-membránon nem jutott át (5. ábra). Ötödik esetünkben multirezisztens Fusarium miatt öszszesen 3 alkalommal végeztünk PKP-t. A Fusarium oxysporum Descemet-membránon történt átjutása már az első PKP esetén igazolható volt, a többszöri mútét ellenére a szemet nem tudtuk megmenteni, enucleatióra került sor (5. eset; 6. ábra). Ötödik esetünknél az enucleatio időpontjáig, a helyes diagnózis felállítását követő 9 hónapon át alkalmaztunk lokális és szisztémás gombaellenes kezelést.

\section{Következtetés}

A fertőzéses eredetú szaruhártya-gyulladások közül a Fusarium-és a Sarocladium-keratitis jelentős diagnosztikai és terápiás kihívást jelent. Ennek oka a gyors progresszió, a késői diagnózis, a mélyebb rétegekbe történő penetrációs hajlam, a gombaellenes terápia korlátozott hozzáférhetősége, valamint a gyakori terápiarezisztencia. Primeren 5\%-os natamicin szemcsepp adandó, és a terápia napi $2 \times 200 \mathrm{mg}$ vorikonazoltabletta szisztémás adásával egészíthető ki Fusarium-keratitis esetén. Közleményünk célja, hogy felhívjuk a figyelmet a kontaktlencse-viselők körében is egyre gyakrabban előforduló Fusarium- és Sarocladium-keratitisre, melyek késői felismerése a gombafonalak Descemet-membránon történő átjutásával az esetek mintegy negyedében a látás és a szemgolyó elvesztésével jár.

Anyagi támogatás: A közlemény megírása, illetve a kapcsolódó kutatómunka anyagi támogatásban nem részesült.

Szerzői munkamegosztás: Sz. N., C. C., I. L., N. Z. Zs.: A vizsgálat tervezése. Sz. N., C. C., I. L., T. J., S. G., H. H., P.-S. A., K. I., B. P., S. Gy.: A vizsgálatok elvégzése. C. C., Sz. N.: A közlemény megírása. S. G., H. H., P.-S. A., K. I., I. L., T. J., B. P., S. Gy., N. Z. Zs., Sz. N.: A közlemény kritikai revíziója. A cikk végleges változatát valamennyi szerző elolvasta és jóváhagyta.

Éedekeltségek: A szerzőknek nincsenek érdekeltségeik.

\section{Irodalom}

[1] Nucci M, Anaissie E. Fusarium infections in immunocompromised patients. Clin Microbiol Rev. 2007; 20: 695-704.

[2] Sanguinetti M, Posteraro B. Identification of molds by matrixassisted laser desorption ionization-time of flight mass spectrometry. J Clin Microbiol. 2017; 55: 369-379.

[3] Nelson PE, Dignani MC, Anaissie EJ, et al. Taxonomy, biology and clinical aspects of Fusarium species. Clin Microbiol Rev. 1994; 7: 479-504.
[4] McCarthy MW, Katragkou A, Iosifidis E, et al. Recent advances in the treatment of scedosporiosis and Fusariosis. J Fungi (Basel) 2018; 4: pii: E73.

[5] Summerbell RC, Gueidan C, Schroers HJ, et al. Acremonium phylogenetic overview and revision of Gliomastix, Sarocladium, and Trichothecium. Stud Mycol. 2011; 68: 139-162.

[6] Tortorano AM, Richardson M, Roilides E, et al. ESCMID and ECMM joint guidelines on diagnosis and management of hyalohyphomycosis: Fusarium spp., Scedosporium spp. and others. Clin Microbiol Infect. 2014; 20(Suppl 3): 27-46.

[7] Jurkunas U, Behlau I, Colby K, et al. Fungal keratitis: changing pathogens and risk factors. Cornea 2009; 28: 638-643.

[8] Ho JW, Fernandez MM, Rebong RA, et al. Microbiological profiles of fungal keratitis: a 10 -year study at a tertiary referral center. J Ophthalmic Inflamm Infect. 2016; 6: 5.

[9] Wang L, Zhang Y, Wang Y, et al. Spectrum of mycotic keratitis in China. Zhonghua Yan Ke Za Zhi 2000; 36: 138-140.

[10] Srinivasan M, Gonzales CA, George C, et al. Epidemiology and aetiological diagnosis of corneal ulceration in Madurai, South India. Br J Ophthalmol. 1997; 81: 965-971.

[11] Rondeau N, Bourcier T, Chaumeil C, et al. Fungal keratitis at the Centre Hospitalier National d'Ophtalmologie des QuinzeVingts: retrospective study of 19 cases. J Fr Ophtalmol. 2002; 25: 890-896. [French]

[12] Dóczi I, Gyetvai T, Kredics L, et al. Involvement of Fusarium spp. in fungal keratitis. Clin Microbiol Infect. 2004; 10: 773776.

[13] Füst Á, Imre L, Simon Gy, et al. Mycotic infection of the cornea. [A szaruhártya gombás eredetú gyulladása.] Szemészet 2015; 152: 159-171. [Hungarian]

[14] Epstein AB. In the aftermath of the Fusarium keratitis outbreak: what have we learned? Clin Ophthalmol. 2007; 1: 355-366.

[15] Mukherjee PK, Chandra J, Yu C, et al. Characterization of Fusarium keratitis outbreak isolates: contribution of biofilms to antimicrobial resistance and pathogenesis. Invest Ophthalmol Vis Sci. 2012; 53: 4450-4457.

[16] Keay LJ, Gower EW, Iovieno A, et al. Clinical and microbiological characteristics of fungal keratitis in the United States, 20012007: a multicenter study. Ophthalmology 2011; 118: 920-926.

[17] Henry CR, Flynn HW Jr, Miller D, et al. Infectious keratitis progressing to endophthalmitis. A 15-year-study of microbiology, associated factors, and clinical outcomes. Ophthalmology 2012; 119: 2443-2449.

[18] Stone D, Tan JF. Fungal keratitis: update for 2014. Curr Ophthalmol Rep. 2014; 2: 129-136.

[19] Alanio A, Beretti JL, Dauphin B, et al. Matrix-assisted laser desorption ionization time-of-flight mass spectrometry for fast and accurate identification of clinically relevant Aspergillus species. Clin Microbiol Infect. 2011; 17: 750-755.

[20] Villani E, Baudouin C, Efron N, et al. In vivo confocal microscopy of the ocular surface: from bench to bedside. Curr Eye Res. 2014; 39: 213-231.

[21] Sharma A, Mohan K, Chander J, et al. Comment on: is inclusion of Sabouraud dextrose agar essential for the laboratory diagnosis of fungal keratitis? Indian J Ophthalmol. 2011; 59: 260-261.

[22] Matoba AY. Fungal keratitis responsive to moxifloxacin monotherapy. Cornea 2012; 31: 1206-1209.

[23] Erie JC, McLaren JW, Patel SV, et al. Confocal microscopy in ophthalmology. Am J Ophthalmol. 2009; 148: 639-646.

[24] Vaddavalli PK, Garg P, Sharma S, et al. Role of confocal microscopy in the diagnosis of fungal and acanthamoeba keratitis. Ophthalmology 2011; 118: 29-35.

[25] Ferrer C, Alió JL. Evaluation of molecular diagnosis in fungal keratitis. Ten years of experience. J Ophthalmic Inflamm Infect. 2011; 1: 15-22.

[26] Sun S, Lui Q, Han L, et al. Identification and characterization of Fusarium proliferatum, a new species of fungi that cause fungal keratitis. Sci Rep. 2018; 8: 4859. 
[27] McGrath LA, Lee GA. Corneal epithelial debridement for diagnosis and therapy of ocular surface disease. Clin Exp Optom. 2015; 98: 155-159.

[28] Lee P, Green WR. Corneal biopsy. Indications, techniques and a report of a series of 87 cases. Ophthalmology 1990; 97: 718721.

[29] Abbouda A, Estrada AV, Rodriguez AE, et al. Anterior segment optical coherence tomography in evaluation of severe fungal keratitis infections treated by corneal crosslinking. Eur J Ophthalmol. 2014; 24: 320-324.

[30] Prajna NV, Krishnan T, Mascarenhas J, et al. The mycotic ulcer treatment trial: a randomized trial comparing natamycin vs. voriconazole. JAMA Ophthalmol. 2013; 131: 422-429.

[31] Wang JY, Wang DQ, Qi XL, et al. Modified ulcer debridement in the treatment of the superficial fungal infection of the cornea. Int J Ophthalmol. 2018; 11: 223-229.

[32] Sun Y, Sun Z, Chen Y, et al. Corneal debridement combined with intrastromal voriconazole for recalcitrant fungal keratitis. J Ophthalmol. 2018; 2018: 1875627.

[33] Hu J, Zhang J, Li Y, et al. A combination of intrastromal and intracameral injections of amphotericin B in the treatment of severe fungal keratitis. J Ophthalmol. 2016; 2016: 3436415.

[34] Yoon KC, Jeong IY, Im SK, et al. Therapeutic effect of intracameral amphotericin B injection in the treatment of fungal keratitis. Cornea 2007; 26: 814-818.

[35] Haddad RS, El-Mollayess GM. Combination of intracameral and intrastromal voriconazole in the treatment of recalcitrant Acremonium fungal keratitis. Middle East Afr J Ophthalmol. 2012; 19: $265-268$.

[36] Behrens-Baumann W, Seibold M, Hofmüller W, et al. Benefit of polyhexamethylene biguanide in Fusarium keratitis. Ophthalmic Res. 2012; 48: 171-176.

[37] Xu Y, Pang GR, Gao CW, et al. Comparison of the activities of silver nitrate with those of three antifungal agents against ocular pathogenic fungi in vitro. Zhonghua Yan Ke Za Zhi 2009; 45: 730-735.
[38] Prajna NV, Krishnan T, Rajaraman R, et al. Adjunctive oral voriconazole treatment of Fusarium keratitis. A secondary analysis from the Mycotic Ulcer Treatment Trial II. JAMA Ophthalmol. 2017; 135: 520-525.

[39] Xie L, Dong X, Shi W, et al. Treatment of fungal keratitis by penetrating keratoplasty. Br J Ophthalmol. 2001; 85: 10701074.

[40] Wykoff CC, Flynn HW Jr, Miller D, et al. Exogenous fungal endophthalmitis: microbiology and clinical outcomes. Ophthalmology 2008; 115: 1501-1507.e2.

[41] Wang Z, Tan XJ, Zhai HL, et al. Etiology and failure analysis of anterior lamellar keratoplasty. Int J Ophthalmol. 2018; 11: 786790.

[42] Gyenes A, Szentmáry, N, Tóth G, et al. Impact of crosslinking on corneal epithelial healing. [Crosslinking kezelés hatása a szaruhártya hámosodására.] Orv Hetil. 2017; 158: 376-379. [Hungarian]

[43] Alshehri JM, Caballero-Lima D, Hillarby C, et al. Evaluation of corneal cross-linking for treatment of fungal keratitis: using confocal laser scanning microscopy on an ex vivo human corneal model. Invest Ophthalmol Vis Sci. 2016; 57: 6367-6373.

[44] Igal V, Pikkel Igal YS, Pikkel YY. Corneal cross-linking as a treatment for fungal keratitis associated with corneal melting. Case Rep Ophthalmol. 2017; 8: 148-151.

[45] Szentmáry N, Módis L, Imre L, et al. Diagnostics and treatment of infectious keratitis. [Fertőzéses keratitisek diagnosztikája és kezelése.] Orv Hetil. 2017; 158: 1203-1212. [Hungarian]

[46] Arboleda A, Miller D, Cabot F, et al. Assessment of rose bengal versus riboflavin photodynamic therapy for inhibition of fungal keratitis isolates. Am J Ophthalmol. 2014; 158: 64-70.e2.

(Czakó Cecília dr., Budapest, Üllői út 26., 1085 e-mail: cecilia.czako@gmail.com)

\section{"Cornix cornici nunquam confodit ocellum." (Lám a szemét sose vájja ki más hollónak a holló.)}

A cikk a Creative Commons Attribution 4.0 International License (https://creativecommons.org/licenses/by/4.0/) feltételei szerint publikált Open Access közlemény, melynek szellemében a cikk bármilyen médiumban szabadon felhasználható, megosztható és újraközölhetö, feltéve, hogy az eredeti szerző és a közlés helye, illetve a CC License linkje és az esetlegesen végrehajtott módosítások feltüntetésre kerülnek. (SID_1) 